\title{
eCommons@AKU
}

January 2016

\section{The effects of cluster-based mentoring programme on classroom teaching practices: Lessons from Pakistan}

Meher Rizvi

Aga Khan University, meher.rizvi@aku.edu

Philip Nagy

University of Toronto

Follow this and additional works at: http://ecommons.aku.edu/pakistan_ied_pdck

Part of the Educational Assessment, Evaluation, and Research Commons, Educational Methods Commons, Other Educational Administration and Supervision Commons, and the Other Teacher Education and Professional Development Commons

\section{Recommended Citation}

Rizvi, M., Nagy, P. (2016). The effects of cluster-based mentoring programme on classroom teaching practices: Lessons from Pakistan. Research Papers in Education, 31(2), 159-182.

Available at: http://ecommons.aku.edu/pakistan_ied_pdck/278 


\section{The effects of cluster-based mentoring programme on classroom teaching practices: lessons from Pakistan}

\section{Meher Rizvi \& Philip Nagy}

To cite this article: Meher Rizvi \& Philip Nagy (2016) The effects of cluster-based mentoring programme on classroom teaching practices: lessons from Pakistan, Research Papers in Education, 31:2, 159-182, DOI: 10.1080/02671522.2015.1029962

To link to this article: http://dx.doi.org/10.1080/02671522.2015.1029962

曲 Published online: 08 Apr 2015.

Submit your article to this journal $\square$

Џلll Article views: 197

Q View related articles $\square$

View Crossmark data ¿ 


\title{
The effects of cluster-based mentoring programme on classroom teaching practices: lessons from Pakistan
}

\author{
Meher Rizvi ${ }^{\mathrm{a} *}$ and Philip Nagy ${ }^{\mathrm{b}}$ \\ ${ }^{a}$ Aga Khan University Institute for Educational Development, 1-5/B-VII, F.B. Area, \\ Karimabad, Karachi 75950, Pakistan; ${ }^{b}$ Measurement and Evaluation, OISE, University of \\ Toronto, 302 Friel Street, Ottawa, ON K1N 1J5, Canada
}

(Received 12 March 2014; accepted 12 March 2015)

\begin{abstract}
This paper presents and evaluates a teacher training approach called the cluster-based mentoring programme (CBMP) for the professional development of government primary school teachers in Pakistan. The study sought to find differences in the teaching practices between districts where the CBMP was used (intervention) and control districts where it was not used (non-intervention). Data were analysed to examine the effectiveness of the CBMP in terms of enhancing teacher practices and student behaviour. The paper differentiates those aspects of classroom teaching where the CBMP has been the most effective and where it has been marginally effective or not effective at all, thus leading to concrete policy lessons for teacher education programmes in Pakistan.
\end{abstract}

Keywords: teacher development; cluster-based mentoring programme; classroom teaching practices

\section{Introduction}

The ultimate aim of any educational effort is to develop successful school learners. For successful preparation of students as active citizens, the role of the teacher is undeniable. Both teachers' content knowledge and pedagogical skills determine effective teaching, and have a positive impact on student achievement. While there is consensus that teachers require a considerable level of expertise in order to fulfil their responsibilities effectively, the debate about the role of teacher education in enhancing teacher effectiveness continues (Clifford and Guthrie 1988; Conant 1963; Goodlad 1990).

In developing countries like Pakistan, the issues pertaining to teacher education and teacher effectiveness become even more pressing. They lack most basic resources including qualified teachers (Barber 2013; Levin and Lockheed 1993). The initial teacher preparation phase is not very productive in terms of imparting required knowledge and skills to teachers (Pre-STEP, Pakistan/USAID 2010). Thus, teacher education is one of the major areas of reform, aiming to prepare teachers who have the capacity to develop students in various cognitive, individual and social skills, and knowledge necessary for becoming effective participants at a variety of levels from classroom to wider community.

*Corresponding author. Email: meher.rizvi@aku.edu 
There are three distinctive school systems in Pakistan. These are:

- Government (public) system of primary and secondary schools

- Private school system (community, non-profit and for-profit schools)

- Religious school (madrassah) system

In the private school sector, principals, teachers, students and community take their schools rather seriously. Madrassahs follow a curriculum heavily dominated by religious subjects (SPDC 2003). However, the government has started redesigning madrassahs' curriculum to also include secular subjects. The major problems with the quality of education in Pakistan are to be found in the government school system (ICG 2004) that caters for three out of five children who attend school. Teaching in government schools is generally characterised as rote learning and memorisation of facts to be regurgitated on internal school exams (Rizvi and Elliott 2007).

Several initiatives have been taken to improve Pakistani government schools, yet very little improvement in the processes of classroom teaching and learning can be observed (SPDC 2003). Thus, there was a need to develop a teacher develop programme which could cater to the learning needs of the children in the government schools. Aga Khan University, Institute for Educational Development (AKU-IED), in working towards its goals of public-private partnerships for enhancing the quality of education in the government school systems, took part in the Education Sector Reform Assistance (ESRA) initiatives to deliver effective and relevant teacher education and development programmes. AKU-IED devised an indigenous approach called cluster-based mentoring programme (CBMP) for the professional education of government primary school teachers in four districts of the province Sindh in the extreme south-west of Pakistan. The central feature of the CBM model is the development of professional competence and skills of the teachers for effective teaching.

A large-scale study was conducted to evaluate the effect of the CBMP at the classroom level, seeking to find differences in the teaching practices between districts where the CBMP has been used (intervention, or I) and control districts where it has not been used (non-intervention, or NI). The dimensions of teaching practices targeted for measurement reflected the training focus of the CBMP within the three core categories of pedagogy, content knowledge and attitude/behaviour. Data were analysed to identify areas where differences between I and NI districts were effective and where they were only marginal or non-existent.

Specifically, the study asked the following questions:

(1) What are the current teaching practices at the school level?

(2) What are the differences in the teaching practices of the I and the NI districts?

(3) How do the students behave in the I and the NI districts?

(4) How effective are the teaching practices and student behaviours of the I and the NI districts?

In the following section of the paper, we briefly describe our conceptualisation of effective classroom teaching. Next, we present general theory on teacher education, which is linked to the intervention context of the study. We then present details of the research study followed by the results and discussion. In the concluding section of the paper, we present limitations of the study and the way forward. 


\section{Effective classroom teaching}

Research has shown that school- and teacher-related factors have a greater influence on student learning outcomes (Avalos 1991) as compared to curriculum and extra school factors. Effective teaching is one of the most essential ingredients for a successful outcome of the teaching and learning process. However, as Fenstermacher and Richardson (2005) propose, defining effective teaching is a complex undertaking. Effective teaching is not only about what is taught but also about how it is taught. So along with appropriate, purposeful and proper content, the methods employed for the impartation of the content should also follow the standards of morally sound and rationally grounded principles of instructional practices. Nevertheless, instructional practices alone will not be effective if they are not complimented by contextual characteristics supportive of students. A supportive social environment, ample opportunity to learn and good practices employed by the teacher trigger the willingness and effort on the part of the learner (Fenstermacher and Richardson 2005).

Levin and Lockheed $(1993,29)$ suggest that at a minimum level effective teaching involves four components: i.e. (i) presenting materials in a rational and orderly manner; (ii) ensuring active student participation; (iii) encouraging students to apply their learning into practice and (iv) giving students feedback on their performance. In addition to method and technique (Davis 2009; Svinicki and McKeachie 2010), more recent conceptions of effective teaching include caring for and support of student learning (Kasworm 2008) and the relationship of learning and human emotions. It is the multidimensional nature of effective teaching which makes measurement of this construct difficult. For the purposes of the study, reported in this paper, effective teaching is conceptualised in terms of three key dimensions - effective content knowledge, effective pedagogy and effective behaviour/attitude. These dimensions reflect effective teaching as a synthesis of a teacher's rational and intuitive capabilities, and are important prerequisites to help teachers in Pakistan achieve policy directives (MoE, GoP 2009) for developing students as self-reliant individuals, capable of analytical and original thinking. Many educators around the world have linked effective teaching to successful learning experiences (McKeachie 1997). Each of these dimensions is now briefly discussed.

\section{Effective content knowledge}

In order to be effective, teachers must decide (1) what to teach, (2) what the students will do to demonstrate learning and (3) what the teacher will do to facilitate learning. In other words, teachers must be able to formulate their teaching objectives and plan lessons that enable them to achieve their objectives. In order to be able to do that effectively, teachers must be aware of educational curriculum and develop links in different subject areas (Cole and Chan 1994; Smith and Lovat 1995).

\section{Effective pedagogy}

Research indicates that facts and information can be learned efficiently through whole class explicit teaching, a direct instruction strategy as well as through cooperative learning groups, an interactive strategy (Muijs and Reynolds 2005). What is important is to make sure that students achieve the learning goals, whether through direct instruction or some form of student-centred approach or through the use of a variety of teaching strategies. Research in Pakistan highlights the employment of variety of 
teaching strategies important for facilitating students' learning (Rizvi 1998; Rizvi and Elliot 2005). Questioning has been identified as one of the most important elements of effective instruction. Another form of effective teaching strategy is carefully prepared classroom discussion (Muijs and Reynolds 2005). Effective teachers are able to prescribe appropriate work tasks that will stimulate student interest and enhance learning. According to Cole and Chan (1994), assessment and evaluation of student performance affect all other aspects of instruction.

\section{Effective behaviour/attitude}

Relationships between teachers and students have been recognised as the most important aspects of positive classroom climate (Muijs and Reynolds 2005) and teacher effectiveness (Rizvi 1998). A teacher can develop rapport with students by showing an interest in them as individuals. Some authors contend that the affective aspects of teaching are more important than methodology. These affective components include, valuing learning, a student-centred orientation and a belief that students can learn (Santrock 2008). Teachers' enthusiasm and expectations of students' work are important determinants of students' classroom performance and achievement (Reynolds et al. 1996).

Generally, teaching practices in developing countries, including Pakistan, do not support the above-mentioned components of effective teaching. There is a general deficiency in teachers' subject-matter knowledge and pedagogical skills (Kizilbash 1998). Teachers rely mostly on notes that they dictate to students. Whole-class instruction is mostly based on lectures by teachers and involves little classroom participation by students. Students are rarely engaged in activities and questions are discouraged. Little or no feedback is given to students on their written work. Monitoring and assessment is not done on an ongoing basis (Levin and Lockheed 1993).

Quality of teaching is inevitably linked with the professional development and training of teachers. In order to develop the teacher, any programme should be concerned with the processes, insights, structures and ideas that enable teachers to reflect about and improve their practices throughout their careers (Smyth 1995).

\section{Teacher development and the CBMP}

Teacher development has been viewed from a variety of perspectives during the past several decades, first, as a training problem, then as a learning problem, and most recently, as a policy problem (Cochran-Smith 2004). During the 1980 to 2000 time period, teacher preparation focused on the education of professionals; that is, the preparation of individuals who both understood content and knew how to teach it. There was also increasing awareness that policies and practices for teacher education need to be based on empirical evidence about the value they add to students' learning outcomes. As a result, a number of learning models have been suggested for the professional development of teachers. Guskey (2000) presents a list of different models which include, training, observation/assessment, involvement in a development/improvement process, study groups, inquiry/action research, individually guided activities and mentoring. Each of these models offers a potential focus for the professional development of teachers. Guskey (2000) suggests that most of these models work in different combinations in the field and no one model can cover all the features of teachers' professional development. 
In the mentoring model of teacher professional development, which is the focus of this paper, a relatively experienced teacher works with a junior to develop him/ her. Although the learning is mutual, usually the experienced teacher offers more input than the protégé. This means that the level of expertise which the junior or relatively inexperienced teacher is expected to employ in his/her classroom must first be acquired by the mentor for effective training, monitoring and supervision of the other individuals. There are several ways a mentor can cascade this training effectively and in cost-efficient way to support teachers in their respective organisations. Developing relationships with teachers and providing them support for enhancing the effectiveness of classroom teaching processes is the core feature of any mentoring programme (Beattie 2001; Shernoff et al. 2011).

AKU-IED's CBM model of teacher development reflects the contextual realities, aiming at the development of professional competence and skills of the government primary school teachers. The CBMP is a cascade model. This means that AKU-IED worked through different layers of development, supervision and implementation. The first layer was the development of the Master Trainers (mentors) at AKU-IED by the specialist AKU-IED faculty. The second layer was the professional development of the teachers (mentees) by the mentors in their own context. The third layer and final layer is when the teachers returned to their contexts and implemented the newly learnt teaching techniques and approaches in their classes.

There is evidence which suggests that cascade teacher training approach, in varying forms, has been particularly effective in the developing world contexts. For example, while evaluating the effectiveness of cascade approach to train nearly 5 million primary school teachers in India, Maheshwari and Raina (1998) report that this strategy, when used with interactive video technology, holds far-reaching promises for improving classroom processes and in-service education of teachers.

\section{The CBMP project}

Careful selection and training of the mentors and mentees were crucial for the successful implementation of the CBM model.

\section{The mentors' selection and training}

The mentors were selected from amongst senior and experienced primary and elementary school teachers. A team faculty from AKU-IED interviewed the nominated teachers. Only those teachers who demonstrated a flexible and empathic attitude and willingness to nurture another person made it to the final selection. A 10 weeks' duration Certificate in Education programme was conducted for 215 participants who were selected for the programme. These graduates became the mentors. The training programme for mentors focused development of communication skills, active listening techniques, effective teaching, supervision and coaching, problem solving, conflict resolution, and skills of reflection and meta-cognition.

\section{The mentees' training}

The mentees (primary school teachers) were selected from the same context as the mentors. They shared the same culture, spoke the same language and had similar contextual knowledge. 
The mentors conducted training programmes for teachers or mentees, intending to create a multiplier effect in improving classroom practice. Each mentor worked with schools within their clusters (vicinities) and trained approximately 25 mentees in multiple cycles. A total of 6302 teachers were trained by the mentors in Sindh province.

The duration of teacher (mentee) training by the mentors was one year and consisted of face-to-face workshops, and field-based follow-up. Through this model, teachers completed 300 contact hours, of which $192 \mathrm{~h}$ were taught through workshops while $108 \mathrm{~h}$ were covered through follow up activities.

\section{Face-to-face workshops}

Every month, mentors conducted four workshops for the mentees in a central school of each cluster. In this way, mentors completed 48 workshops in 1 year. The main purpose was to develop teachers' pedagogical skills. Teachers were imparted knowledge of teaching methods such as activity based learning, cooperative learning, brainstorming, questioning skills, problem-solving methods and role play. It was expected that after completion of workshops teachers would be able to create better lesson plans, engage students in interactive learning and further enhance their pedagogical content knowledge in core subject areas. The face-to-face component also provided the teachers with opportunities to critically reflect upon their current instructional approaches and discuss ways of addressing educational issues.

\section{Field based follow-up component}

Each workshop was followed by a field-based component where the teachers went back to their respective schools and implemented new pedagogical skills. The mentors observed teachers' classes and provided feedback. The mentors also assisted the teachers in lesson planning. Other follow-up activities included conferencing, meetings and observing students' work. The mentors provided nine hours of field-based follow-up in a month.

\section{Expected outcomes of the CBMP}

It was expected that at the end of the CBMP teachers would be able to demonstrate improvement in their pedagogical knowledge and skills; develop confidence; critically reflect upon their practices; exhibit change in their attitudes and beliefs; develop skills of effective classroom management; develop low- and no-cost materials; and encourage student participation in class activities.

Specifically, the dimensions of classroom teaching that CBMP aimed to develop can be grouped into three main categories:

(1) Content knowledge - Content-based teaching in core subjects, such as, mathematics, science, social studies and language. Re-conceptualising traditional teaching, understanding about curriculum, integration and enrichment.

(2) Pedagogy - Cooperative learning, low-cost high-thought instructional material, active learning, inquiry-based learning, questioning skills, problem solving, brain storming, role play, storytelling, discussion, peer coaching, and team teaching.

(3) Attitude/Behaviour - Humanistic attitude, critical thinking and reflective thinking. 


\section{Methods}

\section{Research design}

A quasi-experimental design was particularly suited to explore the effects of the CBMP in natural classroom settings (Muijs 2004). The study sought to find differences in the teaching practices between I districts where the CBM Programme has been used and control NI districts where it has not been used.

\section{Sampling decisions}

There are 23 districts in Sindh. The CBMP was implemented in the four districts of Sindh. These became the I districts. Likewise, four other districts from Sindh were selected as the NI or comparison districts. The NI districts were as comparable as possible to the I districts in terms of teachers' background, educational environment and geographical similarity.

Each district is further divided into several sub-administrative units called talukas. Two talukas of each district were selected on the basis of an urban-rural distinction using a cluster sampling technique. Each district head quarter's taluka was considered to be the urban taluka, while a rural taluka was selected considering issues such as access to and availability of the teachers. The number of selected teachers from each taluka was proportionate to the number of trained teachers in each taluka. Simple random sampling techniques were used to draw the required sample from each stratum (male and female). The study sample comprised 544 government primary school teachers from the four I districts and 544 government primary school teachers from the NI districts. The teachers were selected from 100 different government primary schools.

\section{Characteristics of the sample}

Table 1 presents the characteristics of teachers in the I and NI groups. The ratio of teachers in the two groups was kept as close as possible.

\section{Description of observation schedule}

The review of the different classroom observation schedules illustrated that an instrument which could encompass all aspects of the CBMP did not exist. Therefore, in the interest of capturing valid and reliable classroom practices, we decided to create an original observation schedule called the cluster-based mentoring observation schedule (CBMOS) and began its construction by seeking to cover the breadth of the CBMP.

The CBMOS reflects the practices inculcated in teachers through the CBMP. Questions one to four are specific checklists of observing teachers' practices in the classroom in terms of various teaching approaches, teaching skills, teaching aids and student evaluation procedures. These checklists reflect the dimensions of classroom teaching embedded within the two core training foci of CBMP - pedagogy and the observable aspects of content knowledge in terms of content delivery. Questions five and six focus on students' participation level in terms of observable behaviours and appearances, and observable aspects of teacher-student relationships, which reflect 
Table 1. Characteristics of the teachers in the I and NI groups.

\begin{tabular}{lcc}
\hline Sampling characteristics & Intervention group & Non-intervention group \\
\hline Gender & 377 & 383 \\
Male & 167 & 161 \\
Female & & \\
Geographical & 343 & 313 \\
Urban & 201 & 231 \\
Rural & & \\
Academic qualification & 29 & 20 \\
Secondary school certificate & 94 & 82 \\
Higher secondary & 258 & 286 \\
Bachelors & 163 & 156 \\
Masters & 325 & 293 \\
Professional qualification & 83 & 70 \\
Primary teaching certificate & 216 & 227 \\
Certificate in teaching & 75 & 59 \\
Bachelors in education & & \\
Masters in education & 349 & 366 \\
Professional experience & 195 & 178 \\
Less than 20 years & & \\
More than 20 years & 135 & 133 \\
Role in the school & 409 & 411 \\
Head teacher & & \\
Teacher &
\end{tabular}

the dimensions included in the CBMP core foci of attitude/behaviour. Enumerators recorded their observations on a three-point scale: not observed (NO), observed but not executed well (ONEW), and observed and executed well (OEW). Specific details about the CBMOS construction and development are published elsewhere (Rizvi 2010).

\section{Data collection procedures}

Each teacher was observed four times for four different class periods. The number of enumerators for each district was calculated keeping in mind the time for data collection and number of teachers to be observed. We knew from pilot study experience that one enumerator could complete observation of approximately 50 teachers in 4 months (excluding the holidays). This meant that we needed 20 enumerators to observe 1088 teachers in 4 months. Enumerators were hired for a period of 4 months which approximately equals to 88 days ( 5 days in a week) to observe the selected number of teachers in each district. Twenty enumerators completed a total of 4352 observations in 4 months. Teachers were observed on different days and across different subjects such as language, mathematics, science, geography, etc. The enumerators were kept blind on the I/NI distinction.

\section{Selection and training of the enumerators}

We hired both male and female enumerators from among the local context in order to minimise entry, communication and accessibility issues. 
In all, six days of training was conducted for the enumerators; a four-day initial training and a two-day follow-up workshop. During the training, a training guide was used to discuss the meaning associated with each item in the observation schedule in order to arrive at a mutually agreed understanding about the CBMOS. The three levels of measurement (NO, ONEW and OEW) were discussed in detail with specific examples and findings gleaned from comments collected during the pilot phase. In this way, criteria for measuring each item on a three-point scale were developed through mutual discussion. Issues related to the administration of CBMOS, sequence of field-based activities and research ethics were also discussed.

A two-day follow-up training workshop took place after the enumerators had been in the field for approximately six weeks. It focused on issues that the enumerators reported they were facing in the field. During the follow-up training, enumerators also revisited the measurement criteria for further clarification.

\section{Data analysis}

The main purpose of the analysis was to identify which items of the observation schedule showed I/NI differences and which did not. The data analysis had three phases:

- Preliminary checks;

- Instrument reliability analysis; and

- Main analysis.

\section{Preliminary checks}

We found that the different subjects were largely balanced across the two treatment conditions, and no observer appeared to be an outlier, that is, awarding far more or far less observations of any of the three levels of measurement (NO, ONEW and OEW) than colleagues. This means that a fair degree of uniformity could be seen in the way observers had recorded their observations. Appendix provide proportions of observations by the enumerators.

\section{Instrument reliability analysis}

Observation schedule was checked for internal consistency, using classical reliability techniques. All subscales had satisfactory internal consistency as shown Table 2.

\section{Main analysis}

Data were examined on a scale-by-scale basis. The items were examined within each question/checklist to identify those that best differentiated between teachers from the I and the NI districts. Data from all four observations of the teacher and classroom were combined to form a single summary observation on a five-point scale. Table 3 shows the decision rules for combining the four observations of the same checklist item.

Because each of the scales consisted of items that showed varying degrees of difference across the intervention/non-intervention groups, exploratory analysis was used to examine the items from this perspective and refine the scales for further work. 
Table 2. Internal consistency of observation subscales.

\begin{tabular}{lc}
\hline Subscale & Cronbach's alpha \\
\hline I. Approaches ( 7 items) & 0.71 \\
II. Techniques used by teacher (14 items) & 0.88 \\
III. Teaching aids (12 items) & 0.72 \\
IV. Student evaluation approaches (9 items) & 0.82 \\
V. Participation and behaviour of students (7 items) & 0.73 \\
VI. Teacher interaction with students (13 items) & 0.88 \\
\hline
\end{tabular}

Table 3. Conversion of individual observations to summary observations.

\begin{tabular}{ll}
\hline Criteria for redefining original ratings & Summary observation and code \\
\hline All observations NO (1) & 1. No evidence of skill \\
At least one ONEW, nothing better (2) & 2. Slight evidence of skill \\
One only OEW and anything else (3) & 3. Beginning evidence of skill \\
Two only OEW and anything else (4) & 4. Moderate evidence of skill \\
Three or more OEW (5) & 5. Consistent evidence of skill \\
\hline
\end{tabular}

\section{Results and discussion}

\section{Examination of treatment differences}

An analysis of the percentages of OEW activities or behaviours in Table 4 illustrates that the occurrence of such activities is higher in the I districts than in the NI districts for all dimensions of effective teaching. In the I districts, teaching techniques demonstrate the highest percentage $(52 \%)$ of OEW activities, followed by student behaviour and participation with $49 \%$ OEW activities. In the NI districts, teaching techniques demonstrate $32 \%$ of OEW activities. However, it is also important to note that overall $36 \%$ of the observations in the I districts did not demonstrate any evidence of the improved skill.

In order to examine the significance of the observable differences, exploratory $t$-tests were applied to all the items at the 0.01 level to minimise problems with Type 1 error. Almost all items showed a significant difference at alpha 0.01 and a large number of differences were significant even at the 0.001 level because of the large number of observations.

Table 4. Percentages of subscales for intervention and non-intervention districts.

\begin{tabular}{lccccccc}
\hline & \multicolumn{3}{c}{ Intervention (I) districts } & & \multicolumn{2}{c}{ Non-intervention (NI) districts } \\
\cline { 2 - 3 } Subscales & NO (\%) & ONEW (\%) & OEW (\%) & & NO (\%) & ONEW (\%) & OEW (\%) \\
\hline Approaches & 46 & 15 & 39 & & 48 & 31 & 21 \\
Techniques & 24 & 24 & 52 & & 32 & 36 & 32 \\
Teaching aids & 58 & 10 & 32 & & 66 & 13 & 22 \\
Evaluation & 32 & 25 & 43 & & 41 & 36 & 23 \\
Student behaviour & 23 & 28 & 49 & & 36 & 36 & 28 \\
Teacher interaction & 33 & 27 & 40 & & 41 & 38 & 21 \\
\hline
\end{tabular}


The key task was to identify those observations that were the best indicators of the intervention. In order to achieve this, a different approach, more akin to an effect size calculation than a statistical test, was developed to give more precise measures of differences in the teaching practices of the teachers.

The ' $4 \mathrm{~s}$ ' - moderate evidences of skill and ' $5 \mathrm{~s}$ ' - consistent evidences of skill (see Table 3) measures were combined for all items and their difference were calculated. $z$-tests on all the differences were performed and some decision rules were developed.

- Items where the differences between I and NI frequencies were equal to or lower than 10.0 were flagged as poor indicators.

- Items where the differences between I and NI frequencies fell between 10.1 and 19.0 were flagged as modest indicators.

- Items where the differences between I and NI frequencies were equal to or greater than 19.1 were flagged as good indicators.

The results pertaining to each of the six subscales in the CBMOS are illustrated in the Tables 5-10 with the 'best bets' asterisked. We use the broad CBMP framework of content knowledge, pedagogy and attitude/behaviour to present and discuss the results in order to clearly explicate the effect of CBM model. Pedagogy and content knowledge dimensions have been combined to facilitate meaningful discussion.

\section{Pedagogy and content knowledge}

Classroom teaching approaches. The data in Table 5 reveal that the teachers from both the I and the NI groups still tend to rely largely on traditional lecture methods.

Table 5. Differences in classroom teaching approaches.

\begin{tabular}{|c|c|c|c|c|c|}
\hline No. & $\begin{array}{l}\text { Teaching } \\
\text { approaches }\end{array}$ & $\begin{array}{l}\text { Intervention }(\mathrm{I}) \\
\% \text { moderate or } \\
\text { consistent }\end{array}$ & $\begin{array}{l}\text { Non-intervention } \\
\text { (NI), \% moderate } \\
\text { or consistent }\end{array}$ & Difference $^{a}$ & Comment \\
\hline 1 & $\begin{array}{l}\text { Cooperative } \\
\text { learning }\end{array}$ & 29.0 & 11.2 & 17.8 & $\begin{array}{l}\text { Modest } \\
\text { differentiation }\end{array}$ \\
\hline 2 & $\begin{array}{l}\text { Inquiry-based } \\
\text { tasks* }\end{array}$ & 44.5 & 8.5 & 36.0 & $\begin{array}{l}\text { Good } \\
\text { differentiation }\end{array}$ \\
\hline 3 & Role play & 5.0 & 2.0 & 2.9 & $\begin{array}{l}\text { Poor } \\
\text { differentiation } \\
\text { too low in I }\end{array}$ \\
\hline 4 & Class discussion* & 63.8 & 18.0 & 45.8 & $\begin{array}{l}\text { Good } \\
\text { differentiation }\end{array}$ \\
\hline 5 & $\begin{array}{l}\text { Small group } \\
\text { discussion }\end{array}$ & 20.6 & 9.0 & 11.6 & $\begin{array}{l}\text { Modest } \\
\text { differentiation }\end{array}$ \\
\hline 6 & $\begin{array}{l}\text { Talk-and-chalk } \\
\text { (lecture) method }\end{array}$ & 86.0 & 59.6 & 26.5 & $\begin{array}{l}\text { Good } \\
\text { differentiation } \\
\text { high in NI }\end{array}$ \\
\hline 7 & $\begin{array}{l}\text { Individual work } \\
\text { (each student } \\
\text { doing his or her } \\
\text { own work) }\end{array}$ & 53.5 & 47.1 & 6.4 & $\begin{array}{l}\text { Poor } \\
\text { differentiation } \\
\text { high in NI }\end{array}$ \\
\hline
\end{tabular}

${ }^{\mathrm{a}}$ All differences significant at $p<.001$ except $\# 7$, significant at $p<.01$. 
However, there are also clear trends among the teachers from the I districts to employ more innovative and constructive teaching approaches such as classroom discussion, cooperative learning and inquiry-based methods (Muijs and Reynolds 2005; Santrock 2008) in a consistent manner. Teachers from the I districts are five times more likely (line 2 , Table $5,44.5$ vs. 8.5 ) to use inquiry approaches such as problem solving, pattern making, story completion, experiments, predictions, multiple-choice responses or pictorial demonstration of ideas. At the same time, it is also important to note that role play, one of the main teaching approaches taught to the CBM teachers at the cluster workshops, is no longer used by the majority of teachers.

Teaching skills. Teachers from the I districts were observed using effective techniques (presenting an overview of the lesson, making clear the purpose of the lesson, using teaching resources, writing clearly on the blackboard and dealing with various class issues) more consistently than in the NI districts. Good differentiation is most noticeable in items 1,9 and 11 of Table 6 . The teachers from the I schools are four times (Line 9, Table 6, 52.9 vs. 14.0) more able to effectively lead students from simple to complex topics, and define relationships between what the students know and what the teacher plans to teach. A high percentage of teachers' performance in items 4, 6, 7 and 8 for both groups should not come as a surprise because generally all the public sector teachers have received pre-service training where skills such as the use of blackboard, giving instructions, etc. are emphasised.

Teaching aids used in the class. Table 7 shows that the most commonly used teaching aids in the two groups are blackboards and textbooks. Teachers from the I districts have demonstrated using these aids more skilfully. The other more commonly used teaching aids are worksheets, objects in the class, charts and pictures. One of the key training focuses in the CBMP was the effective preparation and use of lowor no-cost materials. However, data illustrate that the CBMP trained teachers are not able to make frequent use of flash cards or other low-cost material. The teaching aid dimension constitutes the lowest percentage $(32 \%)$ of OEW activities in the I districts. Previous research (Rizvi and Elliott 2007) has shown that the government primary school teachers who are trained in the effective use of teaching with flash cards and low or no cost material give up the use of these aids when they are not provided with either financial, material or human support, as is often the case.

Student evaluation approaches. The most common approaches used by the teachers in the I and the NI districts to evaluate students' performance are asking lower level questions and correcting written tasks and oral responses. It is evident from Table 8 that the teachers from the I districts are able to use these techniques more effectively. These teachers highlight good points as well as areas for improvement with specific suggestions of how these can be improved.

Moreover, teachers from the I districts are more consistent and more effective in the use of advanced evaluation approaches such as asking higher order questions, asking students to give examples to demonstrate their understanding of the topic, observing student activities and correcting activity-based tasks. Good differentiation can best be observed in items 1,5 and 7. The data illustrate that student evaluation procedures in the I districts are more diverse and focused towards facilitating 
Table 6. Differences in the teaching skills.

\begin{tabular}{|c|c|c|c|c|c|}
\hline No. & $\begin{array}{l}\text { Techniques used by } \\
\text { the teachers }\end{array}$ & $\begin{array}{l}\text { I, } \% \text { moderate } \\
\text { or consistent }\end{array}$ & $\begin{array}{l}\text { NI, \% moderate } \\
\text { or consistent }\end{array}$ & Difference $^{a}$ & Comment \\
\hline 1 & $\begin{array}{l}\text { Makes clear } \\
\text { statement of the } \\
\text { purpose of the } \\
\text { lesson* }\end{array}$ & 76.1 & 40.8 & 35.3 & $\begin{array}{l}\text { Good } \\
\text { differentiation, } \\
\text { marginally } \\
\text { high in NI }\end{array}$ \\
\hline 2 & $\begin{array}{l}\text { Defines relationship } \\
\text { of this lesson to } \\
\text { previous lessons }\end{array}$ & 25.9 & 6.4 & 19.5 & $\begin{array}{l}\text { Good } \\
\text { differentiation, } \\
\text { low in I }\end{array}$ \\
\hline 3 & $\begin{array}{l}\text { Presents overview } \\
\text { of the lesson }\end{array}$ & 36.2 & 15.1 & 21.1 & $\begin{array}{l}\text { Good } \\
\text { differentiation, } \\
\text { low in I }\end{array}$ \\
\hline 4 & $\begin{array}{l}\text { Gives clear } \\
\text { instructions }\end{array}$ & 77.6 & 60.1 & 17.5 & $\begin{array}{l}\text { Modest } \\
\text { differentiation, } \\
\text { high in NI }\end{array}$ \\
\hline 5 & $\begin{array}{l}\text { Uses teaching } \\
\text { resources } \\
\text { effectively }\end{array}$ & 65.8 & 37.3 & 28.5 & $\begin{array}{l}\text { Good } \\
\text { differentiation, } \\
\text { marginally } \\
\text { high in NI }\end{array}$ \\
\hline 6 & $\begin{array}{l}\text { Writes clearly on } \\
\text { the blackboard }\end{array}$ & 87.9 & 74.1 & 13.8 & $\begin{array}{l}\text { Modest } \\
\text { differentiation, } \\
\text { too high in NI }\end{array}$ \\
\hline 7 & Speaks clearly & 91.5 & 86.0 & 5.5 & $\begin{array}{l}\text { Poor } \\
\text { differentiation, } \\
\text { too high in NI }\end{array}$ \\
\hline 8 & $\begin{array}{l}\text { Uses vocabulary } \\
\text { that is } \\
\text { understandable by } \\
\text { the students }\end{array}$ & 87.1 & 74.3 & 12.9 & $\begin{array}{l}\text { Modest } \\
\text { differentiation, } \\
\text { too high in NI }\end{array}$ \\
\hline 9 & $\begin{array}{l}\text { Presents topics with } \\
\text { a logical sequence* }\end{array}$ & 52.9 & 14.0 & 39.0 & $\begin{array}{l}\text { Good } \\
\text { differentiation }\end{array}$ \\
\hline 10 & $\begin{array}{l}\text { Paces lesson } \\
\text { appropriately }\end{array}$ & 65.8 & 39.5 & 26.3 & $\begin{array}{l}\text { Good } \\
\text { differentiation, } \\
\text { marginally } \\
\text { high in NI }\end{array}$ \\
\hline 11 & $\begin{array}{l}\text { Summarises major } \\
\text { points of lesson }\end{array}$ & 36.2 & 13.4 & 22.8 & $\begin{array}{l}\text { Good } \\
\text { differentiation, } \\
\text { marginally low } \\
\text { in I }\end{array}$ \\
\hline 12 & $\begin{array}{l}\text { Responds to } \\
\text { problems raised } \\
\text { during lesson* }\end{array}$ & 57.0 & 9.2 & 47.8 & $\begin{array}{l}\text { Good } \\
\text { differentiation }\end{array}$ \\
\hline 13 & $\begin{array}{l}\text { Relates today's } \\
\text { lesson to future } \\
\text { lessons }\end{array}$ & 20.6 & 7.5 & 13.1 & $\begin{array}{l}\text { Modest } \\
\text { differentiation, } \\
\text { low in I }\end{array}$ \\
\hline 14 & $\begin{array}{l}\text { Provides students } \\
\text { with opportunities } \\
\text { to practice new } \\
\text { ideas }\end{array}$ & 28.9 & 11.2 & 17.6 & $\begin{array}{l}\text { Modest } \\
\text { differentiation, } \\
\text { low in I }\end{array}$ \\
\hline
\end{tabular}

${ }^{a}$ All differences significant at $p<.001$ except \#7, significant at $p<.01$.

students' learning. However, the low score of 24.3 in item 9 appears to suggest that these procedures are still quite teacher dominated. Many students are not provided with opportunities to evaluate their own work. 
Table 7. Differences in the teaching aids used in the class.

\begin{tabular}{|c|c|c|c|c|c|}
\hline No. & $\begin{array}{l}\text { Teaching } \\
\text { aids }\end{array}$ & $\begin{array}{l}\text { I, } \% \text { moderate } \\
\text { or consistent }\end{array}$ & $\begin{array}{l}\text { NI, \% moderate } \\
\text { or consistent }\end{array}$ & Difference $^{\mathrm{a}}$ & Comment \\
\hline 1 & Worksheets & 55.5 & 47.2 & 8.3 & $\begin{array}{l}\text { Poor differentiation, } \\
\text { too high in NI }\end{array}$ \\
\hline 2 & Flash cards & 6.3 & 4.0 & 2.2 & $\begin{array}{l}\text { Poor differentiation, } \\
\text { too low in I }\end{array}$ \\
\hline 3 & $\begin{array}{l}\text { Class } \\
\text { objects* }\end{array}$ & 41.4 & 12.9 & 28.5 & Good differentiation \\
\hline 4 & Art work & 10.3 & 5.5 & 4.8 & $\begin{array}{l}\text { Poor differentiation, } \\
\text { low in I }\end{array}$ \\
\hline 5 & Blackboard & 92.6 & 85.7 & 7.0 & $\begin{array}{l}\text { Poor differentiation, } \\
\text { too high in NI }\end{array}$ \\
\hline 6 & Text books & 93.0 & 84.6 & 8.5 & $\begin{array}{l}\text { Poor differentiation, } \\
\text { too high in NI }\end{array}$ \\
\hline 7 & $\begin{array}{l}\text { Story/ } \\
\text { Reference } \\
\text { books }\end{array}$ & 2.8 & 2.8 & 0.0 & $\begin{array}{l}\text { No difference, too } \\
\text { low in I }\end{array}$ \\
\hline 8 & Charts* & 43.4 & 15.4 & 27.9 & Good differentiation \\
\hline 9 & Pictures & 27.9 & 15.6 & 12.3 & $\begin{array}{l}\text { Modest difference, } \\
\text { low in I }\end{array}$ \\
\hline 10 & Games & 2.8 & 0.2 & 2.6 & $\begin{array}{l}\text { Poor differentiation, } \\
\text { too low in I }\end{array}$ \\
\hline 11 & $\begin{array}{l}\text { Ready-made } \\
\text { models }\end{array}$ & 9.0 & 1.3 & 7.7 & $\begin{array}{l}\text { Poor differentiation, } \\
\text { too low in I }\end{array}$ \\
\hline 12 & $\begin{array}{l}\text { Low-cost } \\
\text { models }\end{array}$ & 8.3 & 1.1 & 7.2 & $\begin{array}{l}\text { Poor differentiation, } \\
\text { too low in I }\end{array}$ \\
\hline
\end{tabular}

${ }^{\mathrm{a}}$ Differences significant at $p<.001$ except $\# 1$ and 4 (.01), \#2 not significant at .10 and \#7 (no difference).

\section{Attitude/behaviour change}

Student participation and behaviour. The data from Table 9 reveal that the behaviour of students from the I districts is significantly different from the students belonging to the NI districts. Good differentiation can be observed in items 1, 2, 3, 4 and 7. Students from the I districts are more actively involved in asking questions, responding to questions, appearing interested in helping each other, and also listening to each others' ideas. They also appear to be more confident about asking pertinent questions and also in responding to questions in the class.

Another important observation is that the students from the I districts get along well with each other. More students are observed talking and interacting with each other around various non-academic issues. More students are also observed listening to each other and taking interest in each others' ideas. The social skills of the students from the I districts appear to be better developed. Literature stresses the role of the teacher in designing activities which provide opportunities to practice these skills while studying (Argyle 1999; Trower, Bryant, and Argyle 1978). The teachers from the intervention districts appear to be playing an important role in providing students space to observe, learn, and practice a required social skill. In this way, the humanistic outcomes of the CBMP are being fulfilled.

Teacher-student relationship. Table 10 shows that the teachers from the I districts are more consistent and moderate appliers of relationship building measures with the 
Table 8. Differences in student evaluation approaches.

\begin{tabular}{|c|c|c|c|c|c|}
\hline No. & Evaluation approaches & $\begin{array}{c}\mathrm{I}, \% \\
\text { moderate or } \\
\text { consistent }\end{array}$ & $\begin{array}{l}\text { NI, } \% \text { moderate } \\
\text { or consistent }\end{array}$ & Difference $^{\mathrm{a}}$ & Comment \\
\hline 1 & $\begin{array}{l}\text { Teacher asking lower } \\
\text { level questions to } \\
\text { assess students' level } \\
\text { of understanding* }\end{array}$ & 77.4 & 45.6 & 31.8 & $\begin{array}{l}\text { Good } \\
\text { differentiation, } \\
\text { too high in NI }\end{array}$ \\
\hline 2 & $\begin{array}{l}\text { Teacher asking higher } \\
\text { level questions to } \\
\text { assess students' level } \\
\text { of understanding }\end{array}$ & 27.8 & 5.9 & 21.9 & $\begin{array}{l}\text { Good } \\
\text { differentiation, } \\
\text { low in I }\end{array}$ \\
\hline 3 & $\begin{array}{l}\text { Teacher asking } \\
\text { students to give } \\
\text { examples for } \\
\text { demonstrating their } \\
\text { understanding }\end{array}$ & 27.8 & 5.0 & 22.8 & $\begin{array}{l}\text { Good } \\
\text { differentiation, } \\
\text { low in I }\end{array}$ \\
\hline 4 & $\begin{array}{l}\text { Teacher observation } \\
\text { of student activities* }\end{array}$ & 56.4 & 28.5 & 27.9 & $\begin{array}{l}\text { Good } \\
\text { differentiation }\end{array}$ \\
\hline 5 & $\begin{array}{l}\text { Teacher correcting } \\
\text { activity based tasks* }\end{array}$ & 46.7 & 15.3 & 31.4 & $\begin{array}{l}\text { Good } \\
\text { differentiation }\end{array}$ \\
\hline 6 & $\begin{array}{l}\text { Teacher correcting } \\
\text { written tasks }\end{array}$ & 65.1 & 51.5 & 13.6 & $\begin{array}{l}\text { Modest } \\
\text { differentiation, } \\
\text { too high in NI }\end{array}$ \\
\hline 7 & $\begin{array}{l}\text { Teacher correcting } \\
\text { oral responses* }\end{array}$ & 82.0 & 45.8 & 36.2 & $\begin{array}{l}\text { Good } \\
\text { differentiation, } \\
\text { high in NI }\end{array}$ \\
\hline 8 & $\begin{array}{l}\text { Teacher providing } \\
\text { feedback on } \\
\text { assessment }\end{array}$ & 33.5 & 13.4 & 20.0 & $\begin{array}{l}\text { Good } \\
\text { differentiation, } \\
\text { marginally low } \\
\text { in I }\end{array}$ \\
\hline 9 & $\begin{array}{l}\text { Student evaluating } \\
\text { their own work }\end{array}$ & 24.3 & 17.5 & 6.8 & $\begin{array}{l}\text { Poor } \\
\text { differentiation, } \\
\text { low in I }\end{array}$ \\
\hline
\end{tabular}

${ }^{\mathrm{a}}$ All differences significant at $p<.001$ except $\# 9$, significant at $p<.01$.

students than the teachers from the NI districts. Teachers from the I districts are six to seven times more likely (Line 8, Table 10, 28.5 vs. 4.4) to respond to non-verbal cues of confusion, boredom and curiosity by interacting with the students in interesting ways and also by talking to them. They are two to three times more likely to develop relationships with the students by listening to them and by encouraging them to ask questions.

\section{Conclusion and implications}

The differences in the teaching practices of the teachers from the I and the NI districts demonstrate the effects of the CBMP. All differences favoured the intervention group over the non-intervention. The detailed $z$-tests were able to show significant differences for all the items in the observation schedule. Further, an examination of the sizes of these effects has shown many important differences between the two groups. However, the results also illustrate that the CBMP has not had the same impact in all the dimensions of effective teaching, and also among all teachers and students. 
Table 9. Differences in student participation and behaviour.

\begin{tabular}{|c|c|c|c|c|c|}
\hline No. & $\begin{array}{l}\text { Participation and } \\
\text { behaviour of students }\end{array}$ & $\begin{array}{c}\mathrm{I}, \% \\
\text { moderate or } \\
\text { consistent }\end{array}$ & $\begin{array}{c}\text { NI, \% } \\
\text { moderate or } \\
\text { consistent }\end{array}$ & Difference $^{a}$ & Comment \\
\hline 1 & Ask questions* & 30.5 & 9.9 & 20.6 & $\begin{array}{l}\text { Good } \\
\text { differentiation }\end{array}$ \\
\hline 2 & Respond to questions* & 79.0 & 20.0 & 59.0 & $\begin{array}{l}\text { Good } \\
\text { differentiation }\end{array}$ \\
\hline 3 & $\begin{array}{l}\text { Help each other in their } \\
\text { studies* }\end{array}$ & 36.6 & 7.2 & 29.4 & $\begin{array}{l}\text { Good } \\
\text { differentiation }\end{array}$ \\
\hline 4 & $\begin{array}{l}\text { Listen to each others' } \\
\text { ideas }\end{array}$ & 50.2 & 18.9 & 31.3 & $\begin{array}{l}\text { Good } \\
\text { differentiation }\end{array}$ \\
\hline 5 & Appear cheerful & 70.4 & 65.8 & 4.6 & $\begin{array}{l}\text { Poor } \\
\text { differentiation, } \\
\text { too high in NI }\end{array}$ \\
\hline 6 & Appear neat and clean & 77.4 & 74.6 & 2.8 & $\begin{array}{l}\text { Poor } \\
\text { differentiation, } \\
\text { too high in NI }\end{array}$ \\
\hline 7 & $\begin{array}{l}\text { Interact with each other } \\
\text { around non-academic } \\
\text { issues }\end{array}$ & 37.5 & 14.7 & 22.8 & $\begin{array}{l}\text { Good } \\
\text { differentiation }\end{array}$ \\
\hline
\end{tabular}

${ }^{\mathrm{a}}$ All differences significant at $p<.001$ except \#5and \#6, not significant at $p<.10$.

Items showing good differentiation were grouped together to illustrate areas where the CBMP has been the most effective in improving classroom teaching practice. Similarly, items demonstrating modest and marginal or no differentiation were brought together. These are given in Appendix.

It is clear from the results in Appendix that the expected outcomes of the CBMP have largely been achieved. Thirty-three out of the sixty-one items (nearly 54\%) are good indicators of intervention. The most dramatic differences, more than $30 \%$, are found in 13 items. In 19 items, the difference is equal to or greater than $20 \%$ but less than $30 \%$. The CBMP has been effective in the development of pedagogical skills such as inquiry-based learning, class discussion and use of teaching resources in different subjects. The development of content knowledge is evident in the way teachers effectively present the topics in a logical sequence, respond to problems raised during the lesson, summarise major points of the lesson and ask higher level questions to assess students' understanding. The picture of government primary schools portrayed through the analysis reflects the characteristics of the child-centred and constructive approaches to teaching and learning (Muijs and Reynolds 2005; Santrock 2008). While activity-based tasks give hands on experience to the students, the inquiry approach enables students to use the highest level of the cognitive domain (Anderson et al. 2001). CBMP's particular focus on reflective practice, critical thinking and humanistic attitude (Santrock 2008) has resulted in teachers listening carefully to students' point of views, treating them in a friendly manner and providing individual attention to students. As a result, students were observed actively helping each other in their studies, listening to each others' ideas, asking questions and responding to questions.

The research has also illustrated that the CBMP has not been able to produce effective result in some areas of classroom teaching. Fifteen out of the sixty-two items (24\%) (see Appendix) demonstrate a marginal or poor effect of the 
Table 10. Differences in teacher-student relationships.

\begin{tabular}{|c|c|c|c|c|c|}
\hline No. & $\begin{array}{l}\text { Teacher interaction with } \\
\text { students }\end{array}$ & $\begin{array}{c}\text { I, } \% \\
\text { moderate } \\
\text { or } \\
\text { consistent }\end{array}$ & $\begin{array}{c}\text { NI, \% } \\
\text { moderate or } \\
\text { consistent }\end{array}$ & Difference $^{\mathrm{a}}$ & Comment \\
\hline 1 & $\begin{array}{l}\text { Listens carefully to the } \\
\text { students' point of views* }\end{array}$ & 78.3 & 23.7 & 54.6 & $\begin{array}{l}\text { Good } \\
\text { differentiation }\end{array}$ \\
\hline 2 & $\begin{array}{l}\text { Offers advice to the } \\
\text { students }\end{array}$ & 37.9 & 22.2 & 15.6 & $\begin{array}{l}\text { Modest } \\
\text { differentiation }\end{array}$ \\
\hline 3 & $\begin{array}{l}\text { Treats students in a } \\
\text { friendly manner* }\end{array}$ & 78.7 & 42.5 & 36.2 & $\begin{array}{l}\text { Good } \\
\text { differentiation }\end{array}$ \\
\hline 4 & $\begin{array}{l}\text { Provides individual } \\
\text { attention to all the students } \\
\text { in his/her class* }\end{array}$ & 62.9 & 35.7 & 27.2 & $\begin{array}{l}\text { Good } \\
\text { differentiation }\end{array}$ \\
\hline 5 & $\begin{array}{l}\text { Encourage students to } \\
\text { involve them in the } \\
\text { learning process }\end{array}$ & 47.1 & 24.6 & 22.4 & $\begin{array}{l}\text { Good } \\
\text { differentiation, } \\
\text { marginally low } \\
\text { in I }\end{array}$ \\
\hline 6 & $\begin{array}{l}\text { Encourages students to ask } \\
\text { questions }\end{array}$ & 34.4 & 13.4 & 21.0 & $\begin{array}{l}\text { Good } \\
\text { differentiation, } \\
\text { marginally low } \\
\text { in I }\end{array}$ \\
\hline 7 & Maintains student attention & 52.6 & 56.6 & -4.0 & $\begin{array}{l}\text { Poor } \\
\text { differentiation, } \\
\text { too high in NI }\end{array}$ \\
\hline 8 & $\begin{array}{l}\text { Responds to nonverbal } \\
\text { cues of confusion, } \\
\text { boredom and curiosity* }\end{array}$ & 28.5 & 4.4 & 24.1 & $\begin{array}{l}\text { Good } \\
\text { differentiation }\end{array}$ \\
\hline 9 & $\begin{array}{l}\text { Paces lesson to allow time } \\
\text { for note taking }\end{array}$ & 47.2 & 36.0 & 11.2 & $\begin{array}{l}\text { Modest } \\
\text { differentiation, } \\
\text { too high in NI }\end{array}$ \\
\hline 10 & $\begin{array}{l}\text { Encourages students to } \\
\text { answer difficult questions* }\end{array}$ & 34.7 & 7.4 & 27.4 & $\begin{array}{l}\text { Good } \\
\text { differentiation }\end{array}$ \\
\hline 11 & $\begin{array}{l}\text { Asks probing questions } \\
\text { when student answer was } \\
\text { incomplete* }\end{array}$ & 46.0 & 7.4 & 38.6 & $\begin{array}{l}\text { Good } \\
\text { differentiation }\end{array}$ \\
\hline 12 & $\begin{array}{l}\text { Restates question and } \\
\text { answers when asked by } \\
\text { students }\end{array}$ & 34.2 & 17.8 & 16.4 & $\begin{array}{l}\text { Modest } \\
\text { differentiation, } \\
\text { marginally low } \\
\text { in I }\end{array}$ \\
\hline 13 & $\begin{array}{l}\text { Communicates to the } \\
\text { students what is expected } \\
\text { of them, why }\end{array}$ & 15.8 & 9.6 & 6.3 & $\begin{array}{l}\text { Poor } \\
\text { differentiation }\end{array}$ \\
\hline
\end{tabular}

${ }^{\mathrm{a}}$ All differences significant at $p<.001$ except \#7, not significant at $p<.10$.

intervention. Some of the 15 items reflect traditional aspects of teaching. In a traditional classroom, the concentration is on lecture or talk-and-chalk method, rote learning of material and testing of memory by taking notes from teachers and reproducing the same during the exams. Since the teachers from government schools typically employ traditional teaching approaches; therefore, teachers from the NI districts have also scored high in these items. This is the main reason for poor differentiation. This section also includes strategies (role play, use of low- or no-cost material, use of worksheets and flash cards) where teachers were specifically trained by the programmes developers. 
The analysis of the various levels of differentiation illustrates that current teaching practices in the selected government primary schools reflect a mixture of both traditional and modern teaching approaches. However, the CBMP has been able to take government primary school teachers' professional capabilities to a greater height. The teachers from the intervention districts were observed performing more complex and challenging teaching tasks than the teachers from the non-intervention districts. Their classrooms comprised children who were confident and who interacted with each other regarding both academic and non-academic matters. The CBM training required teachers to teach and relate with children in ways which were quite different from how the government primary school teachers usually teach (Hoodbhoy 1998; Warwick and Reimers 1995). The teachers from the non-intervention districts still relied to a great extent on the traditional teacher-centred approaches.

The CBMP concluded its programmatic activities in 2007; however, its impact could still be seen in 2009/2010 when the study, reported in this paper, was conducted. The findings illustrate that the teacher development programmes with 'mentoring' focus have the potential to produce an impact which lasts longer than many other teacher training models where the impact has been reported to have died soon after the reform activities ceased (McLaughlin 1997; Rizvi and Elliott 2007).

The success of CBMP can be attributed to its design, where a small number of teacher educators at AKU-IED selected and developed some experienced government primary school teachers as mentors, who mentored other teachers in their contexts in the effective teaching skills. There is a strong likelihood that the government primary school teachers who mostly worked under the top-down centralised system, found the friendly horizontal mentor-mentee channels of communication more conducive for deep learning. Furthermore, the designing of the mentees' workshops with intervening intervals suggest that the programme developers recognised the importance of helping teachers learn through professional development programmes and then embedding teachers' learning in everyday activities (Lieberman 1996; McLaughlin 1997). So, teacher learning did not stop at the workshops. The teachers continued to learn in the school by engaging in professional dialogues with each other through group discussions.

The CBMP has exposed teachers to an innovative learning model. This is a powerful tool in teachers' hands to develop 'horizontal' learning networks among each other rather than always look for 'vertical' help from the top. By entering into mentor-mentee relationships through mutual consent and cooperation, teachers can take charge of their own learning and can keep the process of learning going on.

The enhancement in students' confidence and social skills as a result of enhancement in teachers' teaching must send important signals to teachers to use these behavioural improvements among students for opening doors towards enhancing their academic performance. Literature abounds with theories of learning which clearly link improvement in students' academic performance with students' confidence, self-efficacy beliefs and social skills such as cooperation and learning from each other (Bramlett, Scott, and Rowell 2000; Marsh 1993).

Marginal differences in areas such as the use of teaching aids (flash cards, and low-cost model), role plays, games, etc. suggest a thorough investigation into the causes of ineffectiveness for greater programme impact. These findings have implications for the educational administrators to provide such working conditions and resources which enable teachers to implement and further develop their professional capabilities. 
The evidence from the CBMP presented here clearly outline for the policymakers the strategies for developing contextually relevant continuous professional development programmes for the school teachers. Around the world, ongoing in-service or job-embedded forms of professional learning are becoming widespread (Darling-Hammond and Lieberman 2012). Moreover, most ongoing teacher education programmes will involve a system of mentoring, whether formal or informal, enabling teachers to share their expertise with one another (Wallace and Gravells 2007). By adopting or adapting the CBMP in meaningful ways, the governments can plan and implement professional development programmes that are more relevant to the teachers', the children's and the school's needs.

\section{Limitations and future research prepositions}

This study has some limitations. Firstly, the evaluation is based on only observer information, which has illustrated strong CBMP impact in some classroom practices and very limited impact in some practices. It is important to explore why the teachers have been able to demonstrate more improvement in certain areas, and very little or no improvement in some other areas. There is a need to focus more broadly on teachers' life and work in future research agenda. Most of the teachers who participated in this study were trained teachers and they had 10 or more than 10 years teaching experience. This means that the teachers have already acquired knowledge through other personal sources. Teachers' prior education and experience need to merge with new developments in teacher learning for the teachers to develop professionally and personally. Therefore, this research recognises that personal factors and issues are important and need to be taken as future research agendas by employing diversified data collection strategies such as interviews. In order to help teachers acquire new ways of thinking about teaching and learning, it is important to explore how teachers think about their work.

Secondly, within the time available to us, we could only manage to observe behavioural aspects of students. The future research agenda must define the student learning outcomes broadly to include student academic achievement, and students' feelings in addition to observable student behaviour. Most of the reform initiatives aiming to improve classroom practices, in particular classroom teaching are based on the premise that the improvement in teaching will ultimately result in enhancing student learning. The school improvement literature also emphasises that for 'real' school improvement to occur it is important that school improvement initiatives at the various levels - district education officers, curriculum, school administrators, principals or teachers - must penetrate deep to bring about improvement in students' learning outcomes (Day 2001).

Lastly, collection of data by 20 different enumerators raised issues of inter-rater agreement. However, these were minimised with the help of systematic and rigorous training procedures used to develop agreement among the 20 observers. As a result, a considerable degree of homogeneity could be developed among the raters and no observer appeared to be an outlier. A final preposition in this paper for the future researchers is to invest considerable time and money in developing the measurement scheme with the enumerators and offering training in two parts to ensure that the enumerators have developed similar understanding regarding the observation tools' language and administration. 


\section{Disclosure statement}

No potential conflict of interest was reported by the authors.

\section{Funding}

This work was supported by the Aga Khan University Research Council [grant number \# 08203IED].

\section{Notes on contributors}

Meher Rizvi, $\mathrm{PhD}$, is an assistant professor of Education in the Institute for Educational Development at the Aga Khan University, Karachi, Pakistan. She has an extensive teaching experience in a range of educational contexts, including primary schools, secondary schools, teacher education colleges, and national and international universities. Her primary research interests include teacher professional development and teacher professionalism, curriculum studies, teaching and learning, educational reforms and educational innovation with particular reference to primary education, and educational leadership.

Philip Nagy, PhD, is Professor Emeritus Ontario Institute for Studies in Education of the University of Toronto. He specialises in measurement and evaluation. He has held several executive positions at the university including Chair, Education Committee, Social Sciences and Humanities Council of Canada, Research; President, Canadian Society for the Study of Education; and President, Canadian Educational Researchers Association.

\section{References}

Anderson, L. W., D. R. Krathwohl, P. W. Airasian, and A. Kathleen. 2001. A Taxonomy for Learning, Teaching, and Assessing. New York: Longman.

Argyle, M. 1999. "The Development of Social Coping Skills." In Learning to Cope, edited by E. Frydenberg, 81-106. New York: Oxford University.

Avalos, B. 1991. Approaches to Teacher Education: Initial Teacher Training. London: Commonwealth Secretariat.

Barber, M. 2013. The Good News from Pakistan. http://www.acasus.com/wp-content/uploads/ 2014/02/R3-The-good-news-from-Pakistan-final.pdf.

Beattie, M. 2001. The Art of Learning to Teach: Preservice Teacher Narratives. Upper Saddle River, NJ: Prentice-Hall.

Bramlett, R. K., P. Scott, and R. K. Rowell. 2000. "A Comparison of Temperament and Social Skills in Predicting Academic Performance in First Graders." Special Services in the Schools 16 (1-2): 147-158.

Clifford, G. J., and J. W. Guthrie. 1988. Ed School: A Brief for Professional Education. Chicago, IL: The University of Chicago.

Cochran-Smith, M. 2004. "The Problem of Teacher Education." Journal of Teacher Education 55 (4): 295-299.

Cole, P. G., and L. Chan. 1994. Teaching Principles and Practice. 2nd ed. New York: Prentice Hall.

Conant, J. 1963. The Education of American Teachers. New York: McGraw Hill.

Darling-Hammond, L., and A. Lieberman, eds. 2012. Teacher Education Around the World: Changing and Practices. London: Routledge.

Davis, B. G. 2009. Tools for Teaching. 2nd ed. San Francisco, CA: Jossey-Bass.

Day, C. 2001. School Improvement for Real. London: Routledge Falmer.

Fenstermacher, G. D., and V. Richardson. 2005. "On Making Determinations of Quality in Teaching." Teachers College Record 107: 183-213.

Goodlad, J. I. 1990. Teachers for Our Nation's Schools. San Francisco, CA: Jossey-Bass.

Guskey, T. R. 2000. Evaluating Professional Development. Thousand Oaks, CA: Corwin.

Hoodbhoy, P., ed. 1998. Education and the State: Fifty Years of Pakistan. Karachi: Oxford University.

ICG (International Crises Group). 2004. Pakistan: Reforming the Education Sector. Islamabad: ICG. 
Kasworm, C. E. 2008. "Emotional Challenges of Adult Learners in Higher Education." New Directions for Adult and Continuing Education 2008 (120): 27-34. doi:10.1002/ace.311.

Kizilbash, H. H. 1998. "Teaching Teachers to Teach." In Education and the State: Fifty Years of Pakistan, edited by P. Hoodbhoy, 103-135. Karachi: Oxford University Press.

Levin, H. M., and M. E. Lockheed, eds. 1993. Effective Schools in Developing Countries. London: Falmer.

Lieberman, A. 1996. "Practices that Support Teacher Development: Transforming Conceptions of Professional Learning." In Teacher Learning: New Policies, New Practices, edited by M. W. Mclaughlin and I. Oberman, 185-201. New York: Teachers College.

Maheshwari, A. N., and V. K. Raina. 1998. "In-service Training of Primary Teachers through Interactive Video Technology: An Indian Experience." International Review of Education 44 (1): 87-101.

Marsh, H. W. 1993. "Academic Self-concept: Theory, Measurement, and Research." In Psychological Perspectives on the Self, edited by J. Suls, 59-98. Hillsdale, NJ: Lawrence Erlbaum.

McKeachie, W. J. 1997. "Good Teaching Makes a Difference - And We Know What It Is." In Effective Teaching in Higher Education: Research and Practice, edited by R. P. Perry and J. C. Smart, 396-408. New York: Agathon Press.

McLaughlin, M. W. 1997. "Rebuilding Teacher Professionalism in the United States." In Beyond Educational Reform: Bringing Teachers Back, edited by A. Hargreaves and R. Evans, 77-93. Buckingham: Open University.

MoE (Ministry of Education), GoP (Government of Pakistan). 2009. National Education Policy 2009. http://planipolis.iiep.unesco.org/upload/Pakistan/Pakistan_National_educa tion policy2009REV.pdf.

Muijs, D. 2004. Doing Quantitative Research in Education with SPSS. London: Sage.

Muijs, D., and D. Reynolds. 2005. Effective Teaching: Evidence and Practice. London: Sage.

Pre-STEP (Preservice Teacher Education Program) Pakistan/USAID. 2010. Rationalization of Preservice Teacher Education Programs in Pakistan. http://pakteachers.org/urdu/pdf/ra tionalization-study-report.pdf.

Reynolds, D., B. P. M. Creemers, D. Hopkins, L. Stoll, and R. Bollen. 1996. Making Good Schools. London: Routledge.

Rizvi, M. 1998. "A Study of Attitudes Towards Teacher Effectiveness Amongst the Selected Educators in Karachi, Pakistan." Master's diss., Karachi University.

Rizvi, M. 2010. "Development of a Classroom Observation Schedule for Measuring the Efficacy of a Teacher Development Programme." Procedia - Social and Behavioral Sciences 2: 654-660.

Rizvi, M., and B. Elliot. 2005. "Teachers' Perceptions of their Professionalism in Government Primary Schools in Karachi, Pakistan." Asia-Pacific Journal of Teacher Education 33 (1): 35-52.

Rizvi, M., and B. Elliott. 2007. "Enhancing and Sustaining Teacher Professionalism in Pakistan." Teachers and Teaching: Theory and Practice 13 (1): 5-19.

Santrock, J. W. 2008. Educational Psychology. 3rd ed. New York: McGraw Hill.

Shernoff, E. S., A. M. Marinez-Lora, S. L. Frazier, L. J. Jakobsons, M. S. Atkins, and D. Bonner. 2011. "Teachers Supporting Teachers in Urban Schools: What Iterative Research Designs Can Teach Us.” School Psychology Review 40 (4): 465-485.

Smith, D. L., and T. J. Lovat. 1995. Curriculum: Action on Reflection Revisited. 3rd ed. Wentworth Fall, NSW: Social Science.

Smyth, J. 1995. Critical Discourses on Teacher Development. London: Cassell.

SPDC (Social Policy and Development Centre). 2003. Social Development in Pakistan: Annual Review 2002-03. Karachi: SPDC.

Svinicki, M., and W. J. McKeachie. 2010. McKeachie's Teaching Tips: Strategies, Research, and Theory for College and University Teachers. 13th ed. Belmont, CA: Wadsworth.

Trower, P., P. Bryant, and M. Argyle. 1978. Social Skills and Mental Health. Pittsburgh, PA: University of Pittsburgh.

Wallace, S., and J. Gravells. 2007. Mentoring. 2nd ed. Glasgow: Learning Matters.

Warwick, D. P., and F. M. Reimers. 1995. Hope or Despair: Learning in Pakistan's Primary Schools. Westport, CT: Praeger. 


\section{Appendix}

Table A1. Proportions of different observations by enumerator.

\begin{tabular}{lccc}
\hline Enumerator $(N=4352$ observations) & NO $(\%)$ & ONEW $(\%)$ & OEW $(\%)$ \\
\hline 1 - Intervention & 39.9 & 25.4 & 34.7 \\
2 - Intervention & 18.7 & 36.1 & 45.2 \\
3 - Intervention & 49.5 & 10.8 & 39.8 \\
4 - Intervention & 43.5 & 17.0 & 39.5 \\
5 - Intervention & 23.0 & 28.8 & 48.2 \\
6 - Intervention & 28.9 & 23.6 & 47.5 \\
7 - Intervention & 30.5 & 21.0 & 48.4 \\
8 - Intervention & 34.0 & 26.5 & 39.5 \\
9 - Intervention & 46.3 & 11.2 & 42.4 \\
10 - Intervention & 49.7 & 14.4 & 35.9 \\
11 - Non-intervention & 50.9 & 30.0 & 19.1 \\
12 - Non-intervention & 36.3 & 42.5 & 21.2 \\
13 - Non-intervention & 36.7 & 39.6 & 23.7 \\
14 - Non-intervention & 46.5 & 40.2 & 14.0 \\
15 - Non-intervention & 65.6 & 10.7 & 23.8 \\
16 - Non-intervention & 29.5 & 37.8 & 32.8 \\
17 - Non-intervention & 38.8 & 29.9 & 31.3 \\
18 - Non-intervention & 42.8 & 27.4 & 29.8 \\
19 - Non-intervention & 39.0 & 38.1 & 22.9 \\
20 - Non-intervention & 54.4 & 16.4 & 29.2 \\
\hline
\end{tabular}

NO: Not observed; ONEW: Observed but not executed well; OEW: Observed and executed well. 
Table A2. The extent of the effectiveness of the teaching practices.

Good differentiation $\quad$ Modest differentiation $\quad$ Poor differentiation

Scale I-classroom teaching approaches

2. Inquiry-based tasks

4. Class discussion

6. Talk-and-chalk (lecture method)

Scale II - teaching skills

1. Makes clear statement of the purpose of the lesson

2. Defines relationship of this lesson to previous lessons

3. Presents overview of the lesson

5. Uses teaching resources effectively

9. Presents topics with a logical sequence

10. Paces lesson appropriately

11. Summarises major points of lesson

12. Responds to problems raised during lesson

Scale III - teaching aids used in the class

3. Objects in the class 9. Pictures

8. Charts

Scale IV - student evaluation approaches
1. Teacher asking lower level questions to assess students'
6. Teacher correcting written tasks level of
3. Role play

7. Individual work

\section{Gives clear instructions 7. Speaks clearly}

6. Writes clearly on the blackboard

8 . Uses vocabulary that is understandable by students

13. Relates today's lesson

to future lessons

14. Provides students

with opportunities to

practice new ideas

2. Teacher asking higher level questions to assess students' level of understanding

3. Asking students to give examples for demonstrating their understanding

4. Teacher observation of student activities

5. Teacher correcting activity based tasks

7. Teacher correcting oral responses

8. Teacher providing feedback on assessment 
Table A2. (Continued).

\begin{tabular}{|c|c|c|}
\hline Good differentiation & Modest differentiation & Poor differentiation \\
\hline \multicolumn{3}{|c|}{ Scale $V$-student participation and behaviour } \\
\hline \multicolumn{2}{|l|}{ 1. Ask questions } & 5. Appear cheerful \\
\hline \multicolumn{2}{|l|}{ 2. Respond to questions } & 6. Appear neat and clean \\
\hline \multicolumn{3}{|l|}{ 3. Help each other in their studies } \\
\hline \multicolumn{3}{|l|}{ 4. Listen to each other's ideas } \\
\hline \multicolumn{3}{|l|}{$\begin{array}{l}\text { 7. Interact with each other around } \\
\text { non-academic issues }\end{array}$} \\
\hline \multicolumn{3}{|c|}{ Scale VI - teacher student relationships } \\
\hline $\begin{array}{l}\text { 1. Listens carefully to the } \\
\text { students' point of views }\end{array}$ & $\begin{array}{l}\text { 2. Offers advice to the } \\
\text { students }\end{array}$ & $\begin{array}{l}\text { 7. Maintains student } \\
\text { attention }\end{array}$ \\
\hline $\begin{array}{l}\text { 3. Treats students in a friendly } \\
\text { manner }\end{array}$ & $\begin{array}{l}\text { 9. Paces lesson to allow } \\
\text { time for note taking }\end{array}$ & $\begin{array}{l}\text { 13. Communicates to the } \\
\text { students what is expected of }\end{array}$ \\
\hline $\begin{array}{l}\text { 4. Provides individual attention to } \\
\text { all the students in his/her class }\end{array}$ & $\begin{array}{l}\text { 12. Restates questions } \\
\text { and answers when asked }\end{array}$ & them and why \\
\hline $\begin{array}{l}\text { 5. Encourage students to involve } \\
\text { them in the learning process }\end{array}$ & by students & \\
\hline \multicolumn{3}{|l|}{$\begin{array}{l}\text { 6. Encourages students to ask } \\
\text { questions }\end{array}$} \\
\hline \multicolumn{3}{|l|}{$\begin{array}{l}\text { 8. Responds to non-verbal cues of } \\
\text { confusion, boredom and } \\
\text { curiosity }\end{array}$} \\
\hline \multicolumn{3}{|l|}{$\begin{array}{l}\text { 10. Encourages students to } \\
\text { answer difficult questions }\end{array}$} \\
\hline $\begin{array}{l}\text { 11. Asks probing questions when } \\
\text { student answer was incomplete }\end{array}$ & & \\
\hline
\end{tabular}

